\title{
Kemampuan Komunikasi Matematis Siswa dalam Menyelesaikan Masalah Matematika Ditinjau dari Perbedaan Kecerdasan Intrapersonal
}

Author:
Riezka Nur Fiqih ${ }^{1}$
Harina Fitriyani ${ }^{2}$
Affiliation:
1,2Universitas Ahmad Dahlan,
Yogyakarta, Indonesia
Corresponding author:
Harina Fitriyani,
harina.fitriyani @ pmat.uad.ac.id
Dates:
Received: $16 / 5 / 2021$
Accepted: $1 / 7 / 2021$
Published: $9 / 7 / 2021$

\section{Author:}

Riezka Nur Fiqih

Affiliation:
1,2 Universitas Ahmad Dahlan,
Yogyakarta, Indonesia

Corresponding author:

Harina Fitriyani,

harina.fitriyani@pmat.uad.ac.id

\section{Dates:}

Received: 16/5/2021

Accepted: $1 / 7 / 2021$

Published: 9/7/2021

\begin{abstract}
Abstrak. Kemampuan komunikasi matematis memiliki peran yang sangat penting dalam pembelajaran matematika karena siswa harus mampu mengkomunikasikan ide matematikanya secara tulisan maupun lisan. Sedangkan untuk memahami potensi diri diperlukan kecerdasan intrapersonal yang memadai. Oleh karenanya tujuan penelitian ini adalah untuk mendeskripsikan kemampuan komunikasi matematis siswa dalam menyelesaikan masalah matematika yang ditinjau dari tingkat kecerdasan intrapersonal siswa. Penelitian ini menggunakan pendekatan kualitatif dengan melibatkan 3 orang siswa kelas VII di salah satu SMP Negeri di Kota Pangkalpinang yang masing-masing memiliki kecerdasan intrapersonal tinggi, sedang dan rendah. Pengambilan data penelitian menggunakan angket kecerdasan intrapersonal, tes materi bangun datar yang terdiri dari 3 butir soal essay dan pedoman wawancara. Adapun analisis data menggunakan model Miles dan Huberman yakni reduksi data, penyajian data dan kesimpulan. Hasil penelitian menunjukkan bahwa kemampuan matematis yang paling baik ditunjukkan oleh subjek berkecerdasan intrapersonal sedang, disusul dengan subjek berkecerdasan intrapersonal rendah dan tinggi. Temuan penelitian ini menunjukkan bahwa tingginya level kecerdasan intrapersonal tidak lantas berbanding lurus dengan kemampuan komunikasi matematis siswa.
\end{abstract}

Kata kunci: Komunikasi Matematis, Kecerdasan Intrapersonal, Masalah Matematika

\begin{abstract}
Since students must express their mathematical ideas in writing or orally, mathematical communication skills are important in studying mathematics. Meanwhile, sufficient intrapersonal intelligence is needed to comprehend self-potential. As a result, the aim of this research is to characterize students' mathematical communication skills in solving mathematical problems in terms of their intrapersonal intelligence level. Three students in class VII at one of Pangkalpinang City's state junior high schools participated in this qualitative research. They all had different levels of intrapersonal intelligence: strong, moderate, and low. The data was retrieved using an intrapersonal intelligence questionnaire, the mathematical test consisted of three items and interview. The Miles and Huberman's model was used to analyze the results. According to the findings, subjects with moderate intrapersonal intelligence had the highest mathematical communication skills, followed by those with low and high intrapersonal intelligence. High levels of intrapersonal intelligence are not directly related to students' mathematical communication abilities, according to the results of this report.
\end{abstract}

Keywords: Mathematical Communication, Intrapersonal Intelligence, Mathematical Problem

\section{Copyright:}

JoMEaL

This work is licensed under a Creative Commons Attribution-ShareAlike 4.0 International License.

Read online:

https://jurnal.unej.ac.id/index.php/JOMEAL/index or scan barcode beside.

\section{How to cite this article:}

Fitriyani, H., \& Fiqih, R. (2021). Kemampuan Komunikasi Matematis Siswa dalam Menyelesaikan Masalah Matematika ditinjau dari Perbedaan Kecerdasan Intrapersonal. Journal of Mathematics Education and Learning, 1(2), 126-136. Retrieved from https://jurnal.unej.ac.id/index.php/JOMEAL/article/view/24252 


\section{Pendahuluan}

Dalam pendidikan ada banyak keterampilan yang harus dikuasai oleh siswa salah satunya yaitu keterampilan abad 21 atau biasanya diistilahkan dengan keterampilan 4C. Keterampilan 4C merupakan kebijakan dari Kurikulum 2013 yang berlaku hingga saat ini. Pada keterampilan 4C siswa dituntut memiliki 4 keterampilan yaitu keterampilan berpikir kritis (Critical thinking skill), keterampilan berpikir kreatif (Creative thinking skill), keterampilan komunikasi (Communication skill) dan keterampilan kolaborasi (Collaborative skill) (Nahdi, 2019). Hal ini juga sejalan dengansalah satu tujuan pembelajaran matematika yang terdapat dalam Permendikbud No. 21 Tahun 2016 tentang standar isi yaitu agar siswa memiliki kemampuan mengkomunikasikan gagasan matematika dengan jelas. Keterampilan mengkomunikasikan gagasan matematika dalam pembelajaran matematika merupakan salah satu aspek dari daya matematika (Fitriyani et al., 2021) yaitu kemampuan komunikasi matematis.

Kemampuan komunikasi matematis adalah kemampuan siswa dalam menyampaikan ide matematika baik secara lisan maupun tulisan (Hodiyanto, 2017). Sedangkan belajar matematika berarti belajar untuk mengerti, mendefinisikan dan mengkomunikasikan ide dan gagasan yang terdapat pada grafik, diagram, gambar, variabel dan simbol (Nofrianto et al., 2017). Dengan demikian, dalam pembelajaran matematika kemampuan komunikasi memiliki peran yang sangat penting, karena dalam pembelajaran matematika siswa harus mampu mengkomunikasikan ide atau gagasan matematikanya secara tulisan maupun lisan. Oleh karena itu, kemampuan komunikasi matematis hendaknya menjadi salah satu kemampuan yang diperhatikan dalam pembelajaran matematika. Sebagaimana disampaikan oleh Wahid (2012) bahwa ada dua alasan pembelajaran matematika hendaknya memperhatikan kemampuan komunikasi matematis yaitu matematika pada dasarnya adalah suatu Bahasa, serta matematika dan belajar matematika merupakan aktivitas sosial. Indikator kemampuan komunikasi matematis yang digunakan dalam penelitian ini mengacu pada pendapat Kadir (2008) yakni menulis (written text), menggambar (drawing), dan expresi matematika (mathematical expression). Indikator menulis dapat diamati ketika siswa mampu menjelaskan ide atau solusi dari suatu permasalahan atau gambar dengan menggunakan bahasa mereka sendiri. Sedangkan pada indikator menggambar, siswa dapat menjelaskan ide atau solusi dari permasalahan matematika dalam bentuk gambar. Adapun ekspresi matematika tampak ketika siswa mampu menyatakan masalah atau peristiwa sehari-hari dalam bahasa model matematika.

Kemampuan komunikasi matematis siswa sedikit banyak dipengaruhi oleh kecerdasan siswa, diantaranya kecerdasan intrapersonal. Kecerdasan intrapersonal merupakan salah satu jenis kecerdasan yang terkait dengan pemahaman tentang diri sendiri (Budiyanta et al., 2019). Siswa yang memiliki kecerdasan intrapersonal dapat memotivasi dirinya dan mengetahui kelebihan dan kelemahannya (Rokhima \& Fitriyani, 2018). Oleh karena itu, kecerdasan intrapersonal penting dimiliki siswa untuk lebih memahami dirinya dan kemampuannya agar dapat menggunakan kemampuan komunikasi matematisnya dalam menyelesaikan masalah matematika.

Adapun materi yang digunakan dalam penelitian ini yaitu bangun datar. Dalam penyelesaian soal materi bangun datar diperlukan penguasaan konsep yang baik, membuat ekspresi matematika, serta membuat ilustrasi permasalahan dalam bentuk gambar. Hasil penelitian Budiyanta (2020) menunjukkan siswa peserta olimpiade masih kurang dalam menyelesaikan soal-soal geometri yang membutuhkan kemampuan berpikir tingkat tinggi khususnya pada tahap evaluasi dan mencipta. Siswa peserta olimpiade tentunya merupakan siswasiswa pilihan di kelasnya. Bila siswa yang terpilih saja masih memiliki kemampuan kurang dalam mengerjakan soal geometri yang membutuhkan berpikir tingkat tinggi, maka bagaimana dengan siswa dengan kemampuan biasa-biasa saja. Kemampuan komunikasi matematis menjadi salah satu kemampuan penting yang harus dimiliki siswa dalam menyelesaikan soal-soal geometri terutama soal-soal dengan tingkat kesulitan tinggi. Karena 
umumnya soal tersebut memerlukan analisa mendalam tentang konsep apa yang akan digunakan untuk mengerjakan, membuat model matematikanya serta memvisualisasikan masalah dalam bentuk gambar, tabel, diagram sesuai kebutuhan soal. Namun sayangnya, permasalahan utama adalah rendahnya kemampuan komunikasi matematis siswa dalam menyelesaikan soal geometri khususnya materi bangun datar (Wijayanto et al., 2018).

Sejauh yang diketahui, belum banyak dijumpai penelitian yang menginvestigasi kemampuan komunikasi matematis siswa yang memiliki kecerdasan intrapersonal berbeda pada materi geometri. Kemampuan komunikasi matematis siswa SMP telah dikaji pada materi Segitiga dan Segiempat (Sriwahyuni et al., 2019; Wijayanto et al., 2018), materi Statitiska (Khadijah et al., 2018), materi Himpunan (Aminah et al., 2018), dan materi Lingkaran dengan memperhatikan perbedaan gender (Diandita et al., 2017). Sedangkan pada jenjang SMA, kemampuan komunikasi matematis dikaji pada materi Komposisi Fungsi (Lutfianannisak \& Sholihah, 2018) dan materi Statistika (Azizah \& Maulana, 2018). Selain itu, kemampuan komunikasi matematis dikaji dari sudut pandang gaya kognitif reflektif-impulsif (Murti \& Fitriyani, 2016), self-concept matematis dan gender (Azhari et al., 2018; Sadikin \& Kaharuddin, 2019), self-confidence (Asuro \& Fitri, 2020), dan self-efficacy (Hendriana \& Kadarisma, 2019). Oleh karena itu, investigasi kemampuan komunikasi matematis siswa SMP berdasarkan kecerdasan intrapersonal pada materi bangun datar menjadi menarik untuk dikaji secara mendalam karena kemampuan komunikasi matematis penting dimiliki siswa dalam pembelajaran matematika. Apalagi bila siswa terlebih dahulu menyadari kecerdasan intrapersonalnya sehingga lebih mampu memahami dirinya dan potensinya. Hal ini diharapkan dapat membantu siswa dalam mengkomunikasikan ide-ide matematikanya dalam pemecahan masalah matematika, khususnya geometri.

Dari paparan di atas, tujuan penelitian ini adalah untuk mendeskripsikan kemampuan komunikasi matematis siswa SMP ditinjau dari perbedaan kecerdasan intrapersonal dalam menyelesaikan masalah-masalah geometri. Kecerdasan intrapersonal siswa dikategorikan menjadi tiga yaitu level tinggi, sedang dan rendah. Hasil kajian ini diharapkan dapat menjadi bahan pertimbangan guru dalam menyusun skenario pembelajaran matematika di kelas serta menambah referensi tentang kemampuan komunikasi matematis dan kecerdasan intrapersonal siswa dalam pembelajaran matematika.

\section{Metode Penelitian}

Penelitian ini menggunakan pendekatan deskriptif kualitatif. Penelitian dilaksanakan di salah satu SMP Negeri di Kota Pangkalpinang pada semester genap tahun ajaran 2019/2020. Subjek penelitian adalah 3 siswa yang masing-masing memiliki kecerdasan intrapersonal dengan kategori tinggi, sedang,dan rendah. Adapun penentuan subjek dalam penelitian ini menggunakan teknik purposive sampling. Sedangkan pengumpulan data menggunakan teknik angket yang diberikan secara online menggunakan Google Form, tes tertulis dan wawancara berbasis tugas. Instrumen bantu pengumpulan data menggunakan angket kecerdasan intrapersonal, soal tes kemampuan komunikasi matematis berbentuk essay terdiri dari 3 pertanyaan seperti pada Gambar 1, dan pedoman wawancara tidak terstruktur untuk menggali data penelitian secara lebih mendalam. 

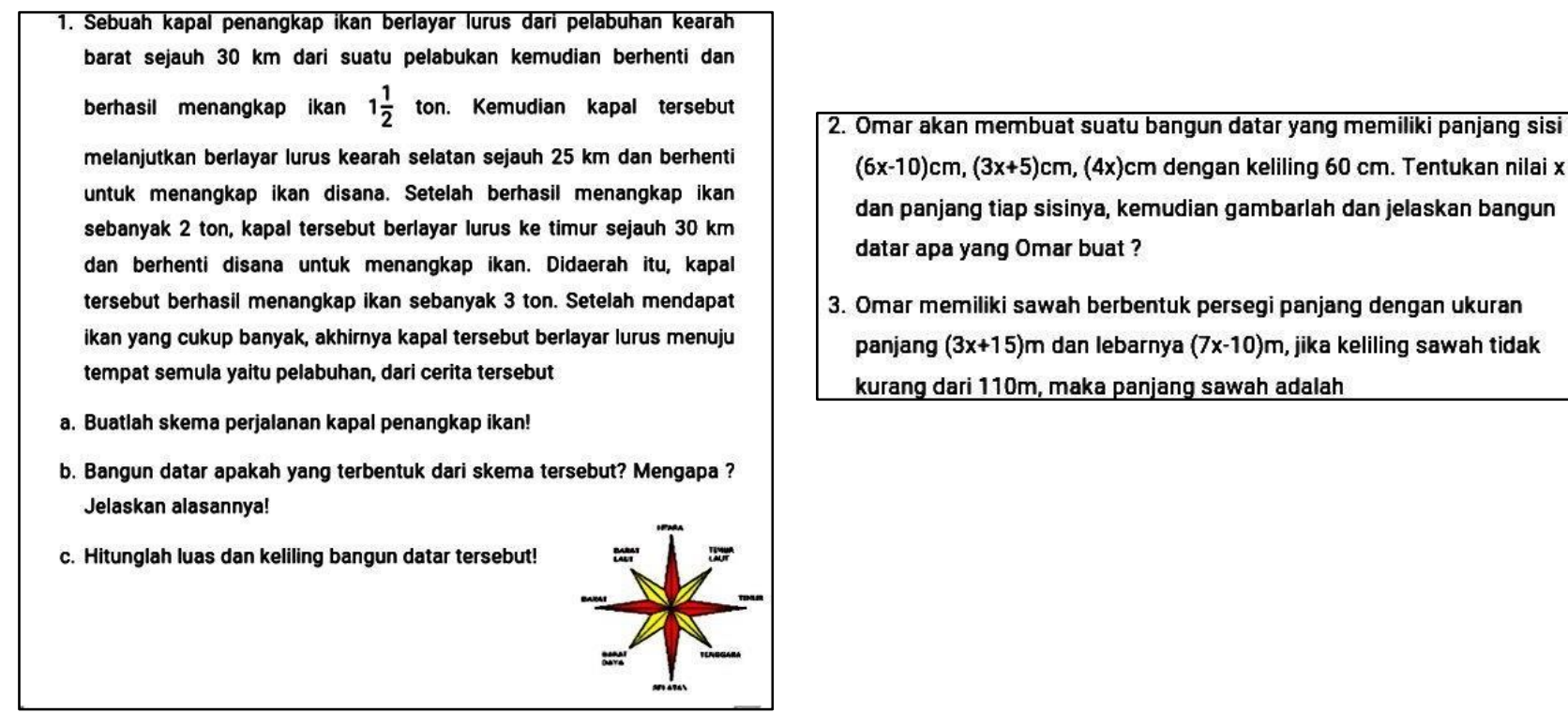

Gambar 1. Soal tes kemampuan komunikasi matematis

Angket kecerdasan intrapersonal menggunakan angket yang dikembangkan oleh Nurokhima (2017, 2018) terdiri dari 40 pernyataan dengan 4 skala pilihan jawaban yaitu Sangat Sesuai (SS), Sesuai (S), Tidak Sesuai (TS) dan Sangat Tidak sesuai (STS). Angket kecerdasan intrapersonal diberikan kepada 64 siswa kelas VII namun hanya 58 siswa yang berpartisipasi. Selanjutnya hasil angket kecerdasan intrapersonal siswa dikelompokkan menjadi tiga yaitu kategori tinggi, sedang dan rendah. Dari hasil pengelompokkan, kemudian dipilih satu siswa dari masing-masing kategori tersebut untuk diteliti lebih lanjut dengan pemberian tes tertulis dan wawancara mendalam. Triangulasi teknik dipilih untuk mendapatkan data penelitian yang jenuh. Sedangkan analisis data pada penelitian ini menggunakan model Miles dan Huberman (2014) yaitu reduksi data, penyajian data dan penarikan kesimpulan.

\section{Hasil dan Pembahasan}

Hasil angket kecerdasan intrapersonal siswa menunjukkan bahwa kecenderungan kecerdasan intrapersonal siswa di sekolah tempat penelitian sebagaimana disajikan pada Gambar 2 berikut.

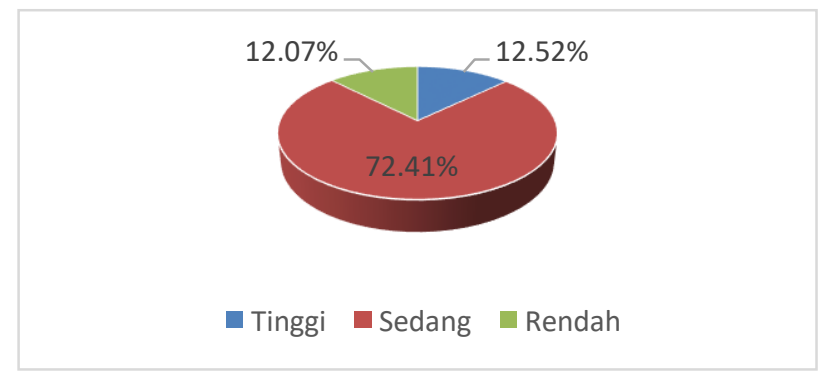

Gambar 2. Pemetaan Kecerdasan Intrapersonal Siswa

Gambar 2 menunjukkan bahwa hasil pemetaan kecerdasan intrapersonal siswa didominasi pada kategori sedang $(72,41 \%)$. Hal ini dapat dipahami bahwa dalam satu kelas, sebagian besar siswa memiliki kecerdasan intrapersonal kategori sedang. Banyaknya siswa yang memiliki kecerdasan intrapersonal tinggi dan rendah sebanding. Temuan penelitian ini sejalan dengan hasil penelitian Budiyanta, dkk 
(2019) dan Rokhima dan Fitriyani (2017, 2018). Namun temuan penelitian ini berbeda dengan hasil temuan Maryati, dkk (2019) yang menyatakan bahwa kecerdasan intrapersonal siswa didominasi kategori tinggi $(64,91 \%)$.

Subjek pada penelitian ini dikategorikan menjadi 3 yaitu siswa dengan kecerdasan intrapersonal tinggi (KT), siswa dengan kecerdasan intrapersonal sedang (KS), dan siswa dengan kecerdasan intrapersonal rendah (KR). Setelah dilakukan tes kemampuan komunikasi matematis, diperoleh hasil jawaban KT seperti pada Gambar 3.

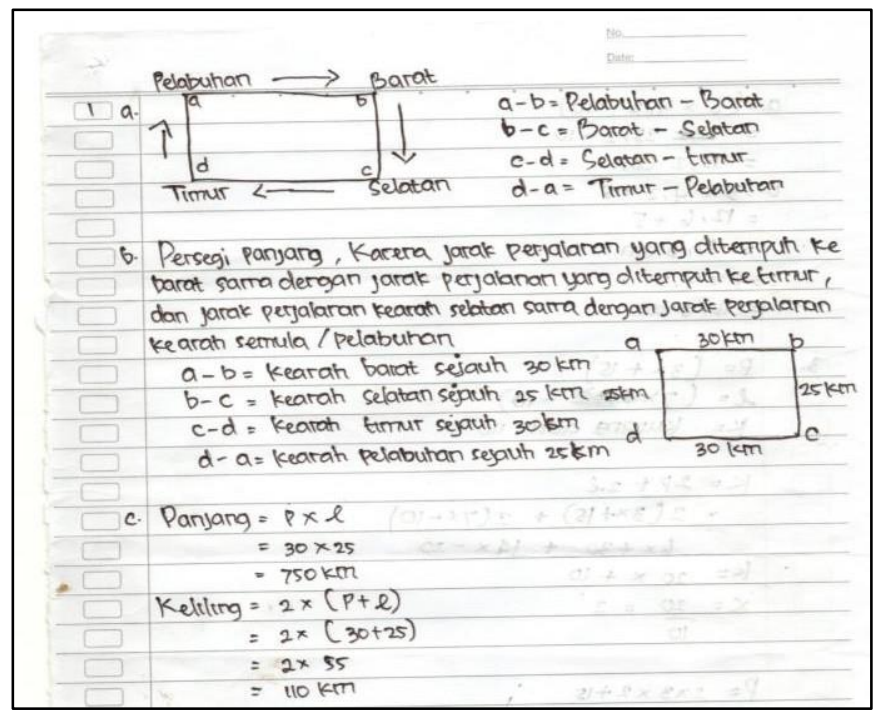

Gambar 3. Jawaban KT pada soal nomor 1

Gambar 3 menunjukkan jawaban KT pada soal nomor 1 dengan indikator menggambar. KT mampu melukiskan gambar namun kurang lengkap dan benar. KT keliru saat memberikan arah pada gambar, arah yang dibuat tidak sesuai dengan arah mata angin pada soal. Pada indikator menulis, KT menuliskan penjelasan yang masuk akal namun hanya sebagian yang benar. KT benar menjawab bangun yang terbentuk dari skema yaitu persegi panjang namun KT kurang tepat ketika mengungkapkan alasannya. KT mengatakan kalau bangun tersebut persegi panjang, namun KT tidak menjelaskan berdasarkan sifatsifat bangun datar tersebut. Pada indikator ekspresi matematika, KT membuat model matematika dengan benar dan melakukan perhitungan secara benar dan lengkap. Di bawah ini cuplikan wawancara yang menunjukkan hal tersebut.

$\mathrm{P} \quad$ : Adik bisa tahu kalau itu bangun persegi panjang alasannya apa?

KT : Dari pelabuhan barat, pelabuhan ke barat sama dengan jarak ke timur dan selatan, selatan ke timur, dari barat ke selatan sama dengan jarak timur kembali ke pelabuhan.

Pada soal nomor 2, KT menuliskan penjelasan yang masuk akal namun hanya sebagian yang lengkap dan benar sebagaimana disajikan pada Gambar 4. KT keliru dalam melakukan perhitungan mencari nilai $x$, jawaban yang seharusnya $=\frac{65}{13}$ namun KT menjawab $x=\frac{55}{13}$. Karena KT salah dalam perhitungan mencari nilai $x$ maka pada perhitungan panjang setiap sisinya, hasil yang diperoleh pun salah. KT juga tidak menuliskan kesimpulan hasil yang telah diperoleh. 


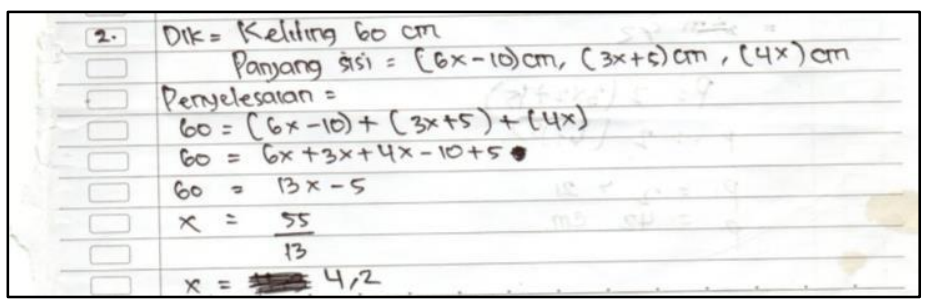

Gambar 4. Jawaban KT pada soal nomor 2

Hasil jawaban tes tertulis menunjukkan KT keliru saat membuat model matematika pada jawaban soal nomor 3 sebagaimana disajikan pada Gambar 5. KT tidak menuliskan keliling yang diketahui sehingga hasil perhitungan yang diperoleh salah. KT juga keliru dalam membuat model matematika ketika mencari panjang sawah, seharusnya KT mencari panjang sawah dengan menggunakan $p=3 x+15$ namun KT menggunakan $p=2(3 x+15)$.

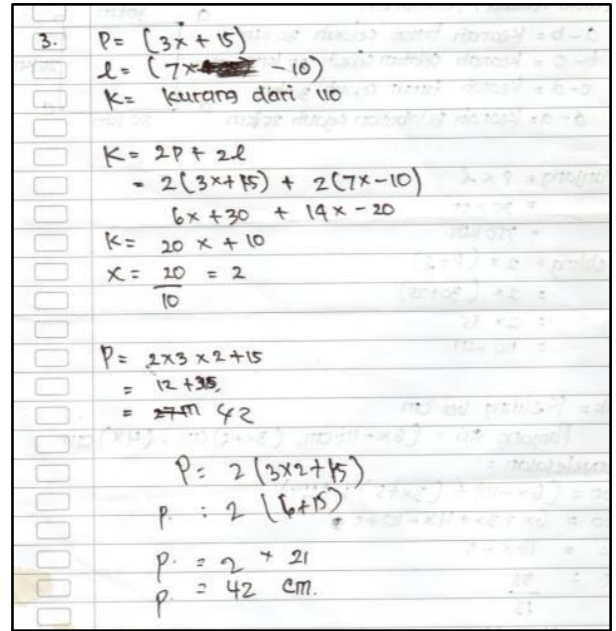

Gambar 5. Jawaban KT pada soal nomor 3

Secara keseluruhan, KT mampu memenuhi indikator menggambar meskipun terdapat sedikit kekeliruan, namun KT tidak memenuhi indikator menulis karena KT kurang mampu untuk menjelaskan dengan bahasa sendiri dan terpaku pada bahasa soal. Hal ini terlihat ketika wawancara dan KT tidak memenuhi indikator ekspresi matematika. KT kurang mampu memodelkan masalah matematika kedalam bentuk matematika.

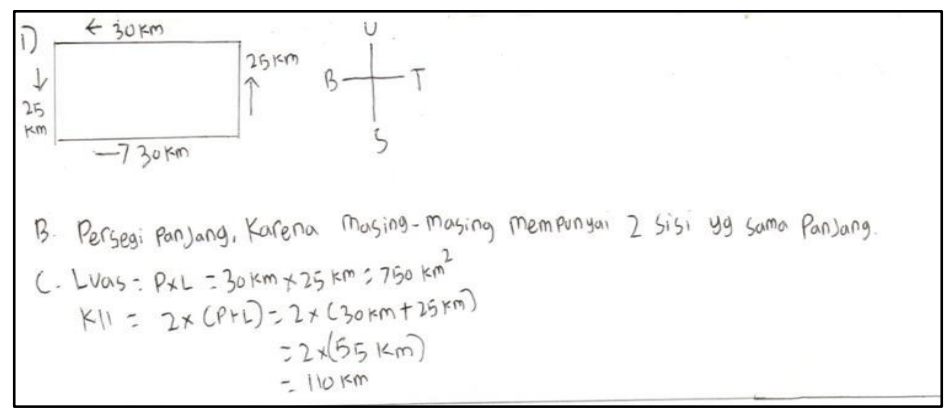

Gambar 6. Jawaban KS pada soal nomor 1

Subjek KS menjawab soal nomor 1 dengan membuat sketsa bangun dan arah mata angin sebagaimana disajikan pada Gambar 6. Hal ini menunjukkan bahwa KS memvisualisasikan soal dengan melukiskan gambar secara lengkap dan benar. Lebih lanjut lagi, dari hasil wawancara diperoleh 
informasi bahwa KS mampu memberikan penjelasan yang matematis dan masuk akal namun hanya sebagian saja yang benar. Berikut cuplikan wawancara yang menunjukkan hal teraebut.

$\mathrm{P} \quad$ : Bagaimana cara adik membuat skema perjalanan kapal penangkap ikannya? Coba jelaskan tahapannya

KS : Yang pertamakan dari pelabuhan pergi kearah barat, jadi mata anginya kearah barat sejauh 30

$\mathrm{P} \quad$ : Terus?

KS : Kemudian, berhenti untuk menangkap ikan 1,5 ton, kemudian kapal itu lanjut berlayar kearah selatan, jadi perginya kearah mata angin selatan

$\mathrm{P} \quad$ : Oke. Lanjut

KS : Setelah itu berhenti menangkap ikan sebanyak 2 ton, lanjut lagi pergi kearah timur, setelah mendapat ikan di sana kembali lagi kesemula, ke pelabuhan. Kembali keutara, udah terbentuklah skema persegi panjang.

Dari hasil tes tertulis dan wawancara menunjukkan bahwa KS benar dalam menjawab bangun apa yang terbentuk dari skema tersebut namun KS tidak mampu menjelaskan alasannya mengapa ia menyatakan bahwa bentuk bangun tersebut persegi panjang dengan bahasa sendiri yang dikaitkan dengan sifat-sifat persegi panjang. KS menjelaskan alasannya hanya terpaku dengan redaksi bahasa soal sehingga terkesan membaca ulang soal yang diberikan. Pada indikator ekspresi matematika, KS membuat model matematika dengan benar serta melakukan perhitungan secara lengkap dan benar.

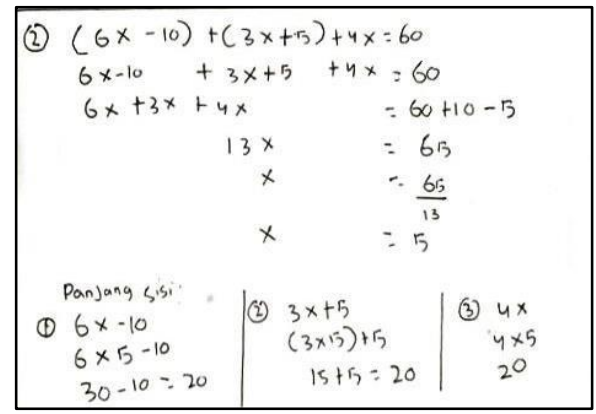

Gambar 7. Jawaban KS pada soal nomor 2

Pada pengerjaan soal nomor 2 seperti disajikan pada Gambar 7, KS menyelesaikan masalah matematika dengan tersusun rapi dan logis namun tidak lengkap. KS tidak menuliskan informasi apa yang diketahui dari soal, tidak menuliskan satuan panjang di setiap hasil perhitungannya namun pada saat wawancara KS menyebutkannya dan KS tidakmenuliskan kesimpulan dari hasil yang telah diperoleh, baik dalam lembar jawaban tes tertulis maupun ketika wawancara.

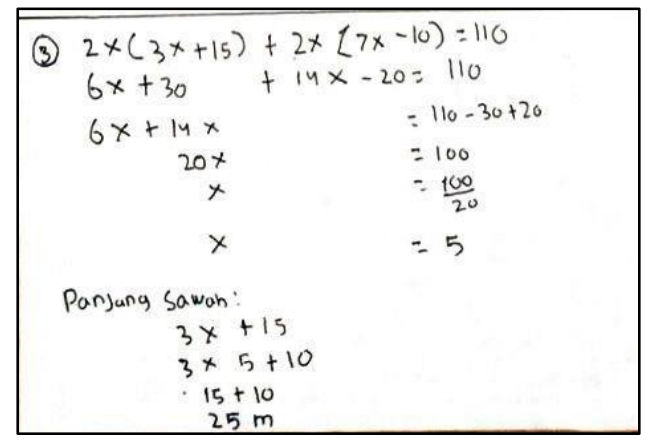

Gambar 8. Jawaban KS pada soal nomor 3

Gambar 8 menunjukkan jawaban KS pada soal nomor 3 dengan indikator ekspresi matematika. KS membuat model matematika dengan benar namun sedikit keliru dalam perhitungan mencari 
panjang sawah. KS menuliskan $3 \times 5+10$. Padahal seharusnya ia menuliskan $3 \times 5+15$ sehingga hasil perhitungan yang diperoleh salah. Namun pada saat wawancara KS menyadari dan memperbaiki jawaban yang salah tersebut. Dari hasil tes tertulis dan wawancara, KS mampu memenuhi indikator menggambar dan ekspresi matematika, KS mampu membuat model matematika meskipun terdapat sedikit kekeliruan pada saat pehitungan pada soal nomor 3, namun KS kurang mampu dalam memenuhi indikator menulis. Hal ini tampak pada jawaban soal nomor 1, KS kurang mampu menjelaskan masalah matematika dengan bahasa sendiri dan terpaku pada bahasa soal sehingga terkesan seperti membaca ulang soal.

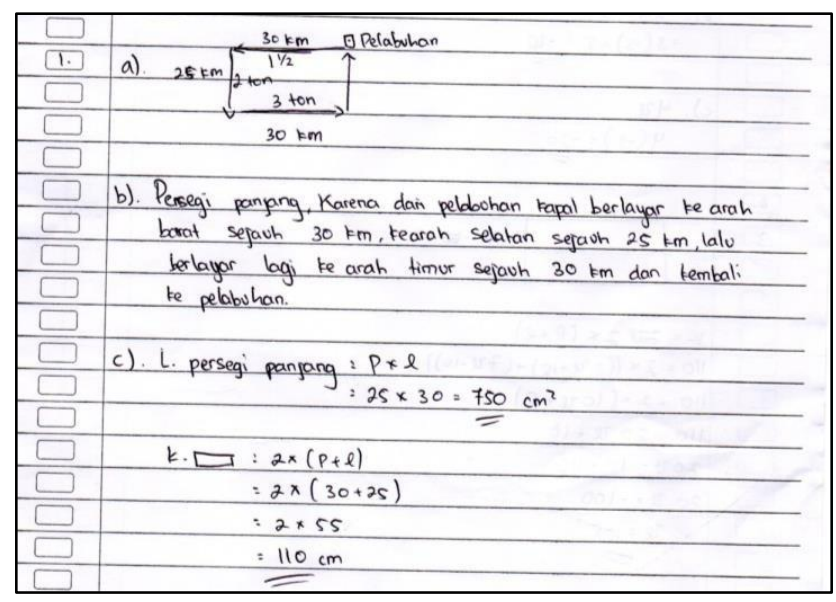

Gambar 9. Jawaban KR pada soal nomor 1

Gambar 9 menunjukkan jawaban KR pada soal nomor 1 pada indikator menggambar. KR memvisualisasikan permasalahan dengan cara melukiskan gambar secara lengkap dan benar. Pada indikator menulis, KR menjawab benar bahwa bangun yang terbentuk dari skema perjalanan kapal penangkap ikan adalah persegi Panjang. Namun KR tidak menjelaskan alasannya menggunakan sifat-sifat persegi panjang dengan bahasa sendiri. KR hanya terpaku pada bahasa soal sehingga terkesan membaca ulang soal. Pada indikator ekspresi matematika, KR membuat model matematika dengan benar, kemudian melakukan perhitungan secara lengkap dan benar.

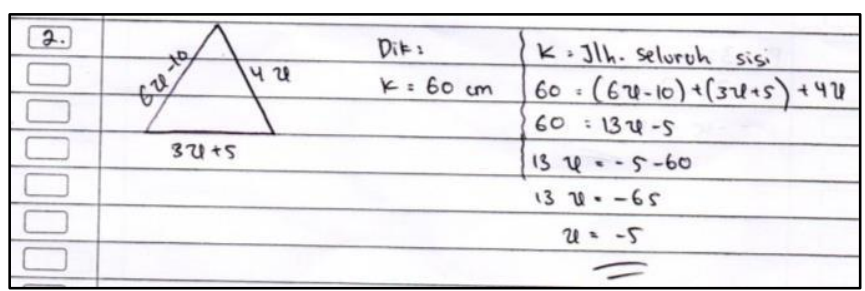

Gambar 10. Jawaban KR pada soal nomor 2

Gambar 10 menunjukkan jawaban KR pada soal nomor 2 dengan indikator menulis. KR tidak menuliskan informasi yang diketahui. KR juga keliru dan kurang teliti dalam melakukan perhitungan. KR menuliskan $13 x=-5-60$, padahal seharusnya $60=13 x-5$. Oleh karenanya nilai $x$ dan panjang setiap sisi yang diperoleh KR keliru. KR juga tidak menuliskan kesimpulan dari hasil yang diperoleh. 


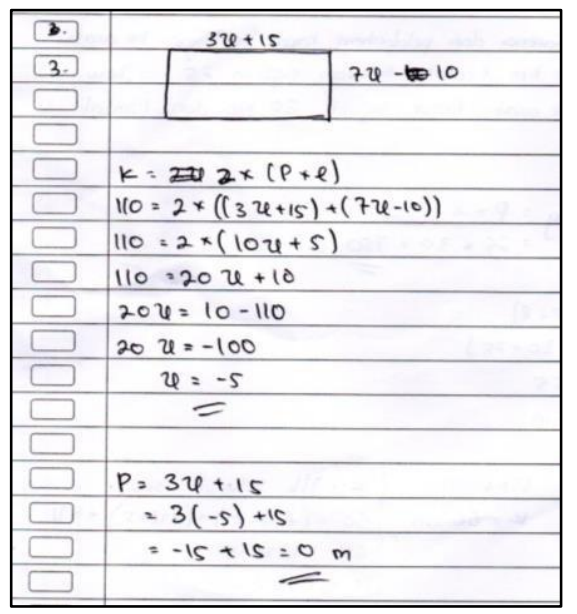

Gambar 11. Jawaban KR pada soal nomor 3

Pada penelusuran indikator ekspresi matematika, KR mampu membuat model matematika dengan benar namun salah dalam melakukan perhitungan. KR keliru pada perhitungan $110=20 x+$ 10 seperti disajikan pada Gambar 11. KR menjawab $20 x=10-110$ padahal seharusnya jawabannya adalah1 $10-10=20 x$. Oleh karenanya nilai $x$ yang diperoleh KR keliru dan KR memperoleh panjang sawah $0 \mathrm{~m}$ yang seharusnya $30 \mathrm{~m}$. Secara keseluruhan KR mampu memenuhi indikator menggambar dan ekspresi matematika, namun masih terdapat sedikit kekeliruan pada saat perhitungan atau mendapatkan solusi. KR tidak memenuhi indikator menulis. KR kurang mampu menjelaskan masalah matematika menggunakan bahasa sendiri tetapi masih terpaku pada soal sehingga terkesan membaca ulang soal. Hasil ini diperkuat dengan cuplikan wawancara sebagai berikut.

$\mathrm{P} \quad$ : Bagaimana langkah-langkah adik untuk menyelesaikan soal ini?

KR : Mencari keliling dulu

$\mathrm{P} \quad$ : Coba jelaskan caranya bagaimana?

KR : Buka kurung 3x tambah 15 tutup kurung tambah buka kurung 7x kurang 10 tutup kurung, 110 sama dengan $2 x$ buka kurung $3 x$ tambah 5 tutup kurung. 110 sama dengan $20 x$ tambah 10 sama dengan 20x sama dengan 10-110, 20x sama dengan min 100, x sama dengan min 5.

$\mathrm{P} \quad$ : Kemudian mencari panjang sawahnya bagaimana?

KR : 3x tambah 5 sama dengan. Salah, 3x tambah 15.

$\mathrm{P} \quad$ : Oke lanjut.

KR : Sama dengan 3 buka kurung min 5 tutup kurung tambah 15 sama dengan min 5 tambah 15 sama dengan (Diam).

$\mathrm{P} \quad$ : Sama dengan?

KR : Sama dengan 0 meter

Secara keseluruhan, kemampuan komunikasi matematis siswa berkecerdasan intrapersonal tinggi, sedang dan rendah disajikan pada Tabel 1 berikut.

Tabel 1. Hasil Analisis Kemampuan Komunikasi Matematis Subjek Penelitian

\begin{tabular}{|c|c|c|c|}
\hline Nomor Soal & KT & KS & KR \\
\hline Persentase & $53,3 \%$ & $83,3 \%$ & $66,7 \%$ \\
\hline
\end{tabular}

Berdasarkan Tabel 1 didapatkan bahwa kemampuan komunikasi matematis subjek dengan kecerdasan intrapersonal tinggi berada pada kategori kurang baik (53,3\%), subjek berkecerdasan intrapersonal sedang berada pada kategori sangat baik $(83,3 \%)$, dan subjek berkecerdasan intrapersonal rendah pada kategori baik $(66,7 \%)$. Hal ini menunjukkan bahwa kemampuan komunikasi matematis subjek 
berkecerdasan intrapersonal sedang lebih unggul diantara yang lain, disusul dengan subjek berkecerdasan intrapersonal rendah dan tinggi. Subjek berkecerdasan intrapersonal tinggi justru memiliki kemampuan komunikasi matematis paling rendah. Padahal seharusnya dengan kecerdasan intrapersonal tinggi tentu lebih baik dalam memahami dirinya dan potensinya sehingga dapat membantunya dalam mengkomunikasikan ide-idenya dalam menyelesaikan tes yang diberikan. Hasil temuan penelitian ini tidak sejalan dengan temuan Marfiah \& Pujiastuti (2020) dan Asuro \& Fitri (2020) yang menemukan bahwa subjek dengan kecerdasan intrapersonal tinggi menunjukkan kemampuan komunikasi matematis paling unggul dibanding yang lainnya.

\section{Kesimpulan}

Hasil investigasi menunjukkan bahwa siswa yang memiliki kecerdasan intrapersonal sedang memiliki kemampuan komunikasi matematis paling unggul dibandingkan dengan siswa pada kategori lainnya dilihat dari indikator menulis (written text), menggambar (drawing), dan expresi matematika (mathematical expression). Demikian juga, siswa dengan kecerdasan intrapersonal rendah justru menunjukkan kemampuan komunikasi matematis lebih baik dari pada siswa dengan kecerdasan intrapersonal kategori tinggi. Temuan penelitian ini mengindikasikan bahwa tingginya level kecerdasan intrapersonal siswa rupanya tidak sebanding dengan level kemampuan komunikasi matematisnya.

\section{Daftar Pustaka}

Aminah, S., Wijaya, T. T., \& Yuspriyati, D. (2018). Analisis Kemampuan Komunikasi Matematis Siswa Kelas VIII Pada Materi Himpunan. Jurnal Cendekia: Jurnal Pendidikan Matematika, 2(1), 15-22. https://doi.org/10.31004/cendekia.v2i1.29

Asuro, N., \& Fitri, I. (2020). Analisis Kemampuan Komunikasi Matematis Ditinjau dari Self-Concept Siswa SMA/MA. Suska Journal of Mathematics Education, 6(1), 033-046.

Azhari, D. N., Rosyana, T., \& Hendriana, H. (2018). Analisis Kemampuan Komunikasi Matematis Siswa SMP Berdasarkan Gender Dan Self Concept. JPMI (Jurnal Pembelajaran Matematika Inovatif), 1(2), 129. https://doi.org/10.22460/jpmi.v1i2.p129-138

Azizah, S. N., \& Maulana, D. F. (2018). Analisis Kemampuan Komunikasi Matematis Pada Siswa SMA. Prosiding SNMPM II, Prodi Pendidikan Matematika, 2010(17), 222-228.

Budiyanta, E., Hendroanto, A., \& Fitriyani, H. (2020). Kemampuan HOTs Siswa SMP dalam Memecahkan Masalah Matematika pada Soal Geometri. Integral: Pendidikan Matematika, 11(1), 1-16.

Budiyanta, E., Sutadi, L. I., \& Fitriyani, H. (2019). Identifikasi Kecerdasan Intrapersonal Siswa Kelas VIII SMP Negeri 7 Yogyakarta. Prosiding Sendika, 5(1), 530-533. http://eproceedings.umpwr.ac.id/index.php/sendika/article/view/796

Diandita, E. R., Johar, R., \& Abidin, T. F. (2017). Kemampuan Komunikasi Matematis Dan Metakognitif Siswa SMP Pada Materi Lingkaran Berdasarkan Gender. Jurnal Pendidikan Matematika, 11(2), 79-97. https://doi.org/10.22342/jpm.11.2.2533.

Fitriyani, H., Setyawan, F., Hendroanto, A., \& Istihapsari, V. (2021). Describing student's mathematical power: Do cognitive styles make any difference? Bulletin of Applied Mathematics and Mathematics Education, 1(1), 39. https://doi.org/10.12928/bamme.v1i1.3856

Hendriana, H., \& Kadarisma, G. (2019). Self-Efficacy dan Kemampuan Komunikasi Matematis Siswa SMP. JNPM (Jurnal Nasional Pendidikan Matematika), 3(1), 153. 
https://doi.org/10.33603/jnpm.v3i1.2033

Hodiyanto, H. (2017). Kemampuan Komunikasi Matematis dalam Pembelajaran Matematika. AdMathEdu, 7(1), 9-18. https://www.neliti.com/publications/177556/kemampuan-komunikasimatematis-dalam-pembelajaran-matematika

Kadir. (2008). Kemampuan komunikasi matematik dan keterampilan sosial siswa dalam pembelajaran matematika. Seminar Nasional Matematika Dan Pendidikan Matematika, 339350.

Khadijah, I. N. A., Maya, R., \& Setiawan, W. (2018). Analisis Kemampuan Komunikasi Matematis Siswa SMP pada Materi Statistika. Jurnal Cendekia: Jurnal Pendidikan Matematika, 1(6), 1095-1104.

Lutfianannisak, L., \& Sholihah, U. (2018). Kemampuan Komunikasi Matematis Siswa dalam Menyelesaikan Soal Materi Komposisi Fungsi Ditinjau dari Kemampuan Matematika. Jurnal Tadris Matematika, 1(1), 1-8. https://doi.org/10.21274/jtm.2018.1.1.1-8

Marfiah, D. ., \& Pujiastuti, H. (2020). Analisis Pengaruh Kecerdasan Intrapersonal terhadap Kemampuan Komunikasi Matematis Siswa pada Materi Bentuk Aljabar. Al Khawarizmi: Jurnal Pendidikan Dan Pembelajaran Matematika, 4(1), 1-15.

Maryati, T., Kasanah, S. U., \& ... (2019). Kontribusi Kecerdasan Intrapersonal Siswa Terhadap Kesadaran Metakognitif Siswa SMK Se-Kota Blitar. Briliant: Jurnal Riset Dan ..., 4, 306-313. http://jurnal.unublitar.ac.id/index.php/briliant/article/view/344

Miles, M., Huberman, M., \& Saldaña, J. (2014). Qualitative Data Analysis: A Methods Sourcebook Thousand Oaks, CA: Sage (3rd ed.).

Murti, D. C., \& Fitriyani, H. (2016). Profil kemampuan komunikasi matematika siswa kelas VII SMP Muhammadiyah 1 Gamping tahun ajaran 2015/2016 berdasarkan gaya kognitif reflektifimpulsif. Seminar Nasional Pendidikan Matematika Ahmad Dahlan, 52-59.

Nahdi, D. S. (2019). Keterampilan Matematika Di Abad 21. Jurnal Cakrawala Pendas, 5(2), 133 140. https://doi.org/10.31949/jcp.v5i2.1386

Nofrianto, A., Maryuni, N., \& Amri, M. A. (2017). Komunikasi Matematis Siswa: Pengaruh Pendekatan Matematika Realistik. Jurnal Gantang, 2(2), 113-121.

Rokhima, N., \& Fitriyani, H. (2017). Pemecahan Masalah Matematika Siswa SMP ditinjau Dari Kecerdasan Interpersonal. Seimnar Nasional Pendidikan, Sains, Dan Teknologi.

Rokhima, N., \& Fitriyani, H. (2018). Student's Metacognition : Do Intrapersonal Intelligent Make Any Difference? Mosharafa: Jurnal Pendidikan Matematika, 7(2). http://journal.institutpendidikan.ac.id/index.php/mosharafa

Sadikin, S., \& Kaharuddin, A. (2019). Identifikasi Kemampuan Komunikasi Matematika Ditinjau Dari Self-Concept Matematis Dan Gender. SNPMAT II, 190-198. https://doi.org/10.31227/osf.io/5fybs

Sriwahyuni, T., Amelia, R., \& Maya, R. (2019). Analisis Kemampuan Komunikasi Matematis Siswa SMP pada Materi Segiempat dan Segitiga. Jurnal Kajian Pembelajaran Matematika, 3(1), 18 23. http://journal2.um.ac.id/index.php/jkpm

Umar, W. (2012). Membangun Kemampuan Komunikasi Matematis Dalam Pembelajaran Matematika. Infinity Journal, 1(1), 1. https://doi.org/10.22460/infinity.v1i1.2

Wijayanto, A. D., Fajriah, S. N., \& Anita, I. W. (2018). Analisis Kemampuan Komunikasi Matematis Siswa SMP Pada Materi Segitiga Dan Segiempat. Jurnal Cendekia: Jurnal Pendidikan Matematika, 2(1), 97-104. https://doi.org/10.31004/cendekia.v2i1.36 